\title{
Long-term variability of occurrence of precipitation forms in winter in Kraków, Poland
}

\author{
Robert Twardosz • Ewa Lupikasza • \\ Tadeusz Niedźwiedź • Adam Walanus
}

Received: 22 March 2011 / Accepted: 7 November 2011/Published online: 25 November 2011

C The Author(s) 2011. This article is published with open access at Springerlink.com

\begin{abstract}
The paper discusses long-term change in snowfall, rainfall and mixed precipitation viewed in conjunction with air temperature and North Atlantic Oscillation (NAO) in winter (December-February). In the study of contemporary climate change and its effect on the hydrological cycle it is useful to focus on winter precipitation forms. A 146-year secular observation series from Kraków, spanning the period 1863-2008, was used to extract data on the number of days with precipitation and on precipitation amount broken down by form. Statistically significant trends were found in total and mixed precipitation, but not in snowfall and rainfall. The climate warming effect has contributed to a material decrease in the snowfall to total winter precipitation ratio during the second half of the 20th c. The highest impact of air temperature was found in the wintertime variation in number of days with snowfall while the NAO had a significant influence on the frequency and amount of both rainfall and snowfall.
\end{abstract}

R. Twardosz $(\bowtie)$

Department of Climatology, Jagiellonian University, ul. Gronostajowa 7, 30-387 Kraków, Poland e-mail: r.twardosz@uj.edu.pl

E. Łupikasza • T. Niedźwiedź

Department of Climatology, University of Silesia, Będzinska 60, 41-200 Sosnowiec, Poland

E. Łupikasza

e-mail: ewa.lupikasza@us.edu.pl

T. Niedźwiedź

e-mail: tadeusz.niedzwiedz@us.edu.pl

A. Walanus

Faculty of Geology, Geophysics and Environmental Protection, AGH University of Science and Technology, al. A. Mickiewicza 30, 30-059 Kraków, Poland

e-mail: walanus@geol.agh.edu.pl 


\section{Introduction}

Studies of contemporary climate change show a strong air temperature increase in recent years. According to the latest report of the Intergovernmental Panel on Climate Change (IPCC 2007) the mean global temperature rose by $0.74^{\circ} \mathrm{C}$ between 1906 and 2005 . It is not so clear, however, what change has occurred in precipitation since this involves a high degree of temporal and spatial variability. This makes any attempt to link it to the global warming phenomenon more complicated.

In Poland the increase in air temperature observed during the second half of the 20th century was accompanied by a decline in annual precipitation totals in lowland areas (Kożuchowski and Żmudzka 2003; Kossowska-Cezak 2009). Projections for Poland derived from the HadCM2 GS climate model involve greater precipitation, especially in winter (Kożuchowski 2004). Potential benefits or drawbacks of the estimated increase in precipitation will depend on the form of that precipitation and on its intensity. A similar question was posed by $\mathrm{H}$. Ye (2008) with relation to the predicted change in precipitation at high latitudes.

In winter, snowfall frequency might be expected to diminish at the expense of rainfall as temperature increases. This proposition may be overly simplistic however. Indeed, regardless of its form (liquid and/or solid) and type (such as thunderstorm precipitation, hailstorm or solidifying precipitation, Twardosz et al. 2011), precipitation depends not only on temperature, but also on the water vapour content in the air and on the topography. H. Ye (2008) aptly pointed out that the complexity of the climate system and the feedback loops involved make it quite difficult to understand dependencies between the type of precipitation and its frequency, especially at high latitudes where the air temperatures in wintertime often remain below freezing point. For this reason research on wintertime precipitation types in moderate and high latitudes is highly significant in the study of contemporary climate change. One example is snowfall, which is regarded as a good indicator for the detection and monitoring of climate change at the global and regional scale (Namias 1985; Jaagus 1997; Hantel et al. 2000; Huntington et al. 2004).

Snowfall research also has a practical aspect related to road and air traffic problems caused by this form of precipitation. At temperatures below $0^{\circ} \mathrm{C}$ solid precipitation leads to a build-up of snow cover, a natural form of water retention. A number of hazardous phenomena are linked to snow cover, such as flash floods or large-scale flooding caused by rapid thaw.

The form and type of precipitation represent a wealth of knowledge about the climate and its changes, but these data are rarely used in climatological research. The reason is that it is notoriously difficult to categorise precipitation forms as this demands the kind of information about weather phenomena that can only be accurately obtained from round the clock visual observations. In Central Europe few meteorological stations offer this kind of long-term record (Hohenpeissenberg in Germany since 1792, Warsaw since 1803, Prague-Klementinum since 1804 or Kremsmünster in Austria since 1820), and Kraków is among these rare places.

In Kraków weather observations started in 1792 and were conducted by astronomers until recently, when they were replaced by professional meteorologists (Twardosz and Cebulska 2010). The record provides an unbroken homogeneous string of quality data on daily precipitation, both numeric and descriptive, since 1863 (Twardosz and Niedźwiedź 2001). Homogeneity of the monthly and annual totals was verified and tested in earlier studies (Niedźwiedź et al. 2009, Twardosz et al. 2010) and was identified at the confidence 
level of 0.05 . Only for freezing precipitation (rain or drizzle) reliable data is available from 1920 onwards (Twardosz et al 2011). Precipitation fluctuations in Kraków have been shown (Niedźwiedź et al. 2009, Twardosz et al. 2010) to be representative for larger region of Central Europe.

This study is concerned with long-term change in wintertime precipitation in terms of the whole season and individual months (December-February). Overall precipitation was stratified into snowfall, rainfall and mixed precipitation, and was linked with air temperature and the North Atlantic Oscillation. The global warming effect, observed during the last few decades, raises the question whether the air temperature increase is indeed followed by changes in the frequency and amount of precipitation of different forms, and what role the NAO plays in this development.

\section{Data and methods}

The study involved the 146-year (1863-2008) observation data series from Kraków, a city located north of the Carpathian Mountains that, together with the Sudeten Mountains, forms a strong climatic barrier dividing Central Europe into two parts (Fig. 1). Kraków receives approximately $10 \%$ more precipitation than other southern Polish stations (Niedźwiedź et al. 2009), but in long-term changes it well represents the large part of Central Europe.

Observations of atmospheric precipitation started in Kraków when a weather station was established in 1792. Until the mid-19th century, observations were limited to the visual method and noted just the presence and the form of precipitation. The era of instrumental measurements of precipitation amount in Kraków began in August 1849.

This has continued ever since, leaving a continuous record, which-uniquely in Central Europe - remained unbroken even during wars. Daily precipitation totals are available from 1863, which is the first year when the measurements can be brought in line with the contemporary precipitation day standard adopted by the Polish weather service, i.e. from 6:00 am to 6:00 pm UTC (Twardosz and Cebulska 2010). The homogenisation of the precipitation observation timing was possible due to a large amount of archive metadata available. Until 1921, measurements were taken three times a day, in the morning, in the afternoon and evening, after which the number of measurements recorded was reduced to just the morning round. Until 1891, observations were scheduled in local time, which was subsequently replaced with the Central European

Fig. 1 Kraków on a map of Central Europe

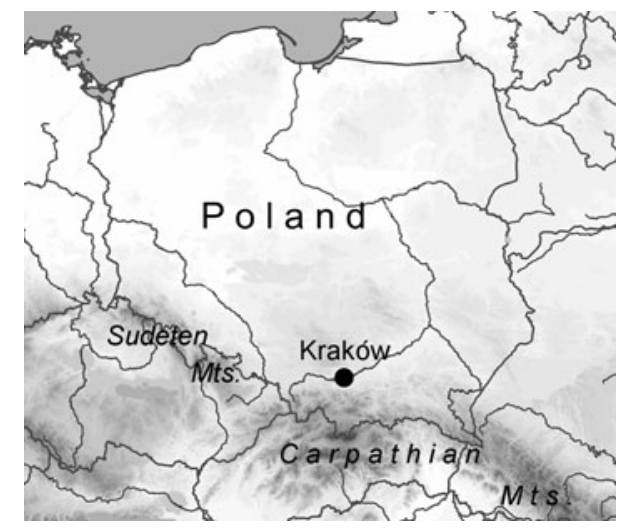


Time (a difference of $20 \mathrm{~min}$ ). Ever since the establishment of the station, the observations were performed by qualified observers, which is a guarantee of high reliability. Astronomers, who were responsible for the observation during most of that period, were replaced by meteorologists in 1950 .

In the 19th century, early pluviometers were replaced with the Hellmann system pluviometers that had smaller catchment surfaces (Twardosz and Cebulska 2010). To bring these measurements to a common denominator daily totals were converted into the area of $200 \mathrm{~cm}^{2}$. This means that the change of the measurement apparatus does not affect the uniformity of the measurement record (Twardosz 1997, 2005).

Totals of daily precipitation $(\geq 0.1 \mathrm{~mm})$ and a description of its form were taken into account to define days with snowfall, rainfall and with mixed precipitation for the whole of the winter season and for its individual months (December, January and February). Days with liquid precipitation were defined as days with only rain or drizzle. Mixed precipitation days include days with sleet, as well as with separate instances of snowfall and rain on the same day. Days with snowfall are equivalent to days with solid precipitation (including snow in various forms, diamond dust, snow crystals, snow grains, ice pellets), except hail, which does not occur in winter. Two characteristics were taken into account, i.e. the number of days with precipitation and the amount, stratified into forms. The various days were coded as follows:

First letter: $\mathrm{P}$ for amount, $\mathrm{N}$ for number of days;

Second letter: $\mathrm{L}$ for liquid precipitation, $\mathrm{M}$ for mixed, $\mathrm{S}$ for snowfall and $\mathrm{T}$ for total precipitation $(\mathrm{L}+\mathrm{M}+\mathrm{S})$,

Third letter denotes individual months: December, January or February (D, J, F).

For example, PS would mean the amount of snowfall in winter, while NSD would mean the number of days with snowfall in December.

A single letter $\mathrm{T}$ denotes mean winter temperature.

We also used the North Atlantic Oscillation (NAO) Index, the most important macro scale index for the European climate, defined by J.W. Hurrell (1995) as the normalized pressure difference between a station on the Azores and one on Iceland. We applied an extended version of the index based on the normalised pressure difference between Gibraltar and Reykjavik (Jones et al. 1997), updated on the Climate Research Unit website (http://www.cru.uea.ac.uk/cru/data/nao.htm).

A linear trend was fitted to the precipitation characteristics. The statistical significances of trend in air temperature and precipitation characteristics in the study period were also determined using the Mann-Kendall test.

Pearson's elementary correlation coefficient was applied to determine a statistical relationship between the precipitation characteristics on the one hand and the air temperature and NAO on the other (von Storch and Zwiers 1999). Principal Components Analysis (PCA) was the method employed to analyse dependencies between the precipitation characteristics, while temperature and time (i.e. the year) were included as additional variables.

The question of trends over time has also been approached by using a standard procedure of feature, i.e. variable, selection (Goyon and Elisseeff 2003) (using Statistica v.9). The method is used to search for variables (among many available) that are capable of explaining a given dependent variable. Such independent variables are sorted according to their predictive power and the top-ones then are included in further calculations. In trend investigation, however, we have applied an approach that 
may be considered the reverse of a typical one. Time was adopted as the dependent variable, i.e. the variable to be explained by other variables. While time is by no means dependent on the amount of snowfall etc., numerically the procedure is correct. The feature selection procedure involves seeking variables capable of explaining the time elapsing, i.e. those exhibiting the trend.

\section{Results and discussion}

\subsection{Number of days and precipitation totals in winter}

In winter, precipitation is recorded on 45 days per year on average in Kraków (Table 1), which means that the probability of a day with precipitation is ca. $50 \%$. Snowfall represented the largest precipitation group and accounted for just under $50 \%$ of days with precipitation in winter (more than $50 \%$ in January). There is a built-up area effect involved resulting from the city-centre location of the weather station which means that the average number of days with snowfall is 10 days lower than in out-of-town locations (Twardosz 2002-2003). This effect is, however, smaller than the effect of orography and atmospheric circulation (Twardosz 2007). Cyclonic circulation from the northeastern sector is known to be the most favourable for snowfall in southern Poland (Twardosz et al. 2010). Rainfall is the second most frequent precipitation forms after snow and it accounts for $31 \%$ of days with precipitation in winter on average. Winter rainfall is linked primarily with cyclonic situations with an advection of warm polarmaritime air masses from the southwestern sector and with the passing of warm fronts (Twardosz et al. 2010, 2011).

Mixed precipitation was the least frequent form with approximately $19 \%$ of all days with precipitation. This form reflects a great variability of weather conditions over Poland that manifests itself in a frequent alternation of warm and cool air masses.

The winter precipitation total is nearly $100 \mathrm{~mm}$ (Table 1 ) and this contributes $14.5 \%$ $\pm 0.4 \%$ of the annual total, which is less than any other season. Nevertheless, winter precipitation is very significant for wildlife, climate and hydrology. This is particularly true of snowfall, which, given appropriate conditions, leads to the development of snow cover that is a form of natural retention of water released later during springtime thaws. Statistical characteristics of the number of wet days and precipitation totals are presented in Table 2.

Snowfall totals are weakly correlated between adjacent months $(r=0.15$ Jan-Feb, $r=$ 0.16 Dec-Jan). As might have been expected, there is no correlation between

Table 1 Average number of wet days $\geq 0.1 \mathrm{~mm}(\mathrm{~N})$ and average precipitation amounts $(\mathrm{P})$ by precipitation form in Kraków (1863-2008) with standard error of the mean

\begin{tabular}{|c|c|c|c|c|c|c|c|c|}
\hline Precipitation form & $\begin{array}{l}\text { Dec. } \\
\text { Average } n\end{array}$ & \multicolumn{2}{|c|}{ Average number of wet days $(\mathrm{N})$} & Winter & \multicolumn{3}{|c|}{ Average precipitation amounts $(\mathrm{P}, \mathrm{mm})$} & $\begin{array}{l}\text { Winter } \\
\text { mm) }\end{array}$ \\
\hline Liquid (L) & $6.0 \pm 0.3$ & $4.2 \pm 0.3$ & $3.9 \pm 0.3$ & $14.1 \pm 0.5$ & $13.7 \pm 1.1$ & $9.4 \pm 0.8$ & $8.2 \pm 0.8$ & $31.3 \pm 1.7$ \\
\hline Mixed (M) & $3.1 \pm 0.2$ & $2.9 \pm 0.2$ & $2.7 \pm 0.2$ & $8.7 \pm 0.3$ & $10.3 \pm 0.8$ & $9.7 \pm 0.8$ & $8.9 \pm 0.7$ & $29.0 \pm 1.4$ \\
\hline Snowfall (S) & $6.2 \pm 0.3$ & $7.8 \pm 0.4$ & $6.8 \pm 0.4$ & $20.9 \pm 0.7$ & $11.6 \pm 0.9$ & $12.8 \pm 0.9$ & $11.7 \pm 1.0$ & $37.2 \pm 1.8$ \\
\hline Total $(\mathrm{T})^{\mathrm{a}}$ & $15.9 \pm 0.4$ & $15.3 \pm 0.4$ & $13.8 \pm 0.4$ & $45.0 \pm 0.7$ & $36.3 \pm 1.5$ & $32.1 \pm 1.4$ & $29.5 \pm 1.4$ & $98.1 \pm 2.5$ \\
\hline
\end{tabular}

a All days with precipitation, including other precipitation types not included in this study 
Table 2 Statistical characteristics of the number of wet days $(\mathrm{N})$ and precipitation amounts $(\mathrm{P})$ by precipitation form in Kraków (1863-2008): standard deviation (first value) and skewness (second value, the standard error of skewness is 0.2 )

\begin{tabular}{|c|c|c|c|c|c|c|c|c|c|c|c|c|c|c|c|c|}
\hline Precipitation form & \multicolumn{6}{|c|}{ Number of wet days (N) } & \multicolumn{2}{|l|}{ Winter } & \multicolumn{6}{|c|}{$\begin{array}{l}\text { Dec. Jan. } \quad \text { Feb. } \\
\text { Precipitation amounts }(\mathrm{P}, \mathrm{mm})\end{array}$} & \multicolumn{2}{|l|}{ Winter } \\
\hline Liquid (L) & 4.0 & 0.5 & 3.1 & 0.8 & 3.1 & 0.6 & 6.5 & 0.6 & 12.7 & 1.4 & 9.0 & 1.7 & 9.7 & 2.1 & 20.0 & 1.2 \\
\hline Mixed (M) & 2.2 & 1.1 & 2.0 & 0.5 & 2.0 & 0.7 & 3.8 & 0.2 & 9.9 & 1.4 & 9.5 & 1.2 & 8.4 & 1.1 & 16.8 & 0.6 \\
\hline Snowfall (S) & 3.9 & 0.8 & 4.5 & 0.9 & 4.4 & 0.6 & 8.4 & 0.5 & 11.9 & 1.9 & 10.2 & 0.9 & 10.7 & 1.8 & 21.1 & 0.8 \\
\hline Total (T) & 4.4 & -0.2 & 4.6 & 0.3 & 4.6 & -0.2 & 8.3 & -0.2 & 17.5 & 0.6 & 16.8 & 0.9 & 16.6 & 1.4 & 29.4 & 0.5 \\
\hline
\end{tabular}

precipitation in February and December $(r=0.04)$. A similar correlation is found in terms of the number of days with snowfall and it becomes even weaker with the other precipitation forms.

Figure 2 shows long-term changes of the precipitation characteristics in question. It is worth noting that the totals of all precipitation forms are strongly (positively) correlated with the number of days with precipitation ( $r=0.75$ on average).

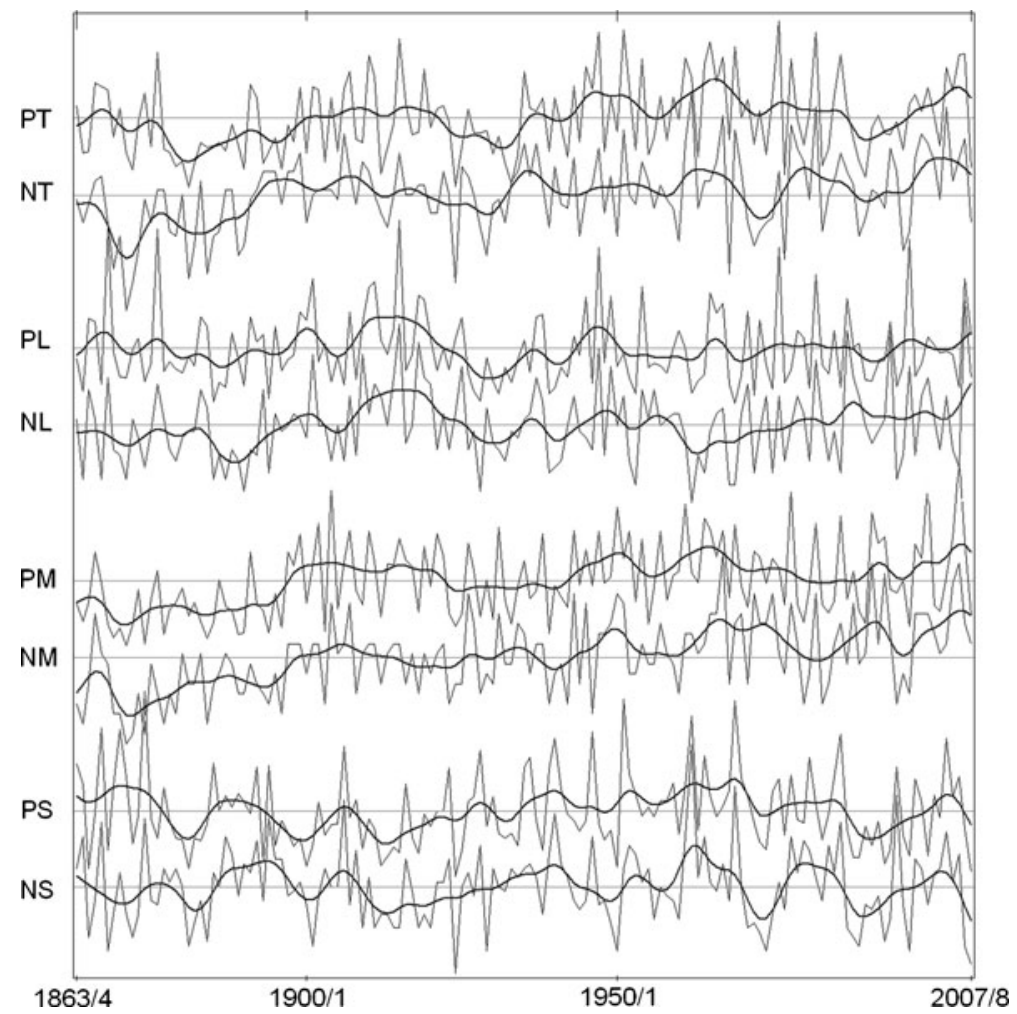

Fig. 2 Comparison of the eight precipitation variables. Precipitation (P) and the number of days (N) are given as pairs for Total precipitation as well as for each given form of precipitation (Liquid, Mixed, and Snow). Smooth curves are obtained by Gaussian filtering with $\sigma=2$ year. The vertical scales are omitted for clarity, averages and standard deviations of the characteristics, see Tables 1 and 2 


\subsection{Changes in precipitation in relation to air temperature}

The observed increase in average winter temperature in Kraków was accompanied by a statistically significant increase in the frequency and amount of total precipitation (Table 3). Despite similarities between these trends, the correlation between temperature and precipitation characteristics was weak at less than 0.2. Mixed precipitation also followed statistically significant trends, but no such trends were found in snowfall and rainfall, either during the entire season or in individual months. With respect to snowfall the findings are corroborated by published research that finds no significant trends in snowfall in various other areas at moderate latitudes (Laternser and Schneebeli 2003; Ke et al. 2009).

The question of time trend has also been approached by the standard procedure of feature selection as mentioned in the Data and methods section. The result is given in Table 4. The eleven variables (including temperature) are found to be significant "predictors" of time. The number of days with mixed precipitation is the best predictor, followed by temperature. This result, including also the less significant predictors, is in good agreement with the result of regression (on time), as well as with the Mann-Kendall test for trend (Table 5).

Figure 3 shows a dependency of the number of days with snowfall on average winter temperature. The correlation is negative, which means that as temperature increases the frequency of snowfall decreases. Specifically an increase of the average winter temperature by $1{ }^{\circ} \mathrm{C}$ corresponds to a drop in the number of days with snowfall by 2.4 (the last item in Table 3). Temperature change accounted for much (42\% of variance) of the variability in the number of days with snowfall.

According to that trend, for an average winter temperature that can go as high as $7.5^{\circ} \mathrm{C}$ the expected number of days with snowfall is nil (the $95 \%$ confidence interval for the temperature is from $6.0^{\circ} \mathrm{C}$ to $9.5^{\circ} \mathrm{C}$ ).

The temperature increase also influenced the duration of the snow cover. M. Hantel et al. (2000) concluded that a temperature increase by $1^{\circ} \mathrm{C}$ would reduce the duration of snow cover in the Austrian Alps by approximately four weeks. Changes in air temperature clearly have a greater impact on the frequency than the amount of snowfall, as demonstrated by the $42 \%$ of frequency variance mentioned above (Table 3 ).

As shown by R.E. Davis et al. (1999) and T.R. Karl et al. (1993) snowfall amount may follow either a positive or negative correlation with temperature. Both studies

Table 3 Time trend of precipitation characteristics as described by linear regression on time (year number). In the last row the result of regression of NS on temperature is given

\begin{tabular}{llccc}
\hline & $\mathrm{R}^{2}$ & Regression coef. & $p$-value & Significance \\
\hline Temp. & 0.128 & $+1.96 \pm 0.43 \mathrm{deg} / 100$ year & 0.00001 & $* * *$ \\
NT & 0.1 & $+6.4 \pm 1.6$ days $/ 100$ year & 0.00007 & $* * *$ \\
PT & 0.04 & $+15.8 \pm 5.7 \mathrm{~mm} / 100$ year & 0.006 & $* *$ \\
NM & 0.24 & $+4.49 \pm 0.66$ days $/ 100$ year & $<0.000001$ & $* * *$ \\
PM & 0.12 & $+13.9 \pm 3.1 \mathrm{~mm} / 100$ year & 0.00002 & $* *$ \\
NL & 0.012 & $+2.1 \pm 1.2$ days $/ 100$ year & 0.1 & - \\
PL & 0.0003 & $-0.7 \pm 0.4 \mathrm{~mm} / 100$ year & 0.85 & Not Sign. \\
NS & 0.0001 & $+0.2 \pm 1.6$ days $/ 100$ year & 0.88 & Not Sign. \\
PS & 0.0007 & $+1.4 \pm 4.2 \mathrm{~mm} / 100$ year & 0.74 & Not Sign. \\
PS/PT (\%) & 0.016 & $-0.06 \pm 0.04 \% / 100$ year & 0.13 & Not Sign. \\
NS/Temp. & 0.42 & $-2.38 \pm 0.23$ days/deg & $<0.000001$ & $* * *$ \\
\hline
\end{tabular}


Table 4 The best time "predictors" i.e. the characteristics which best exhibit the time trend. Variables are sorted according to the value of the statistic F; the resulting $p$-value is also given. The characteristics with $p>$ 0.05 are omitted

\begin{tabular}{llllllllllll}
\hline Var. & NM & T & NMF & NMJ & PMJ & PM & NT & NMD & PMD & NTF & NTJ \\
\hline F & 5.5 & 3.7 & 3.7 & 3.4 & 3.3 & 3.2 & 2.9 & 2.9 & 2.3 & 2.1 & 2.1 \\
$p$-value & 0.000002 & 0.0003 & 0.002 & 0.002 & 0.004 & 0.002 & 0.003 & 0.006 & 0.03 & 0.03 & 0.03 \\
\hline
\end{tabular}

concluded that what determined the index of such a correlation was the location of the measurement point, which was also responsible for the range of mean monthly temperatures. Where the mean monthly temperature is relatively high the correlation is negative and viceversa. This effect is consistent with the Clausius-Clapeyron formula that defines conditions for water vapour condensation. Indeed, higher steam concentration in warmer air results in higher snowfall amount and, as demonstrated by H. Ye (2008), its frequency.

A certain inconsistency was noticed in the trends and correlations between precipitation and temperature. While the amount of snow precipitation (PS) and the number of days with snowfall (NS) are strongly correlated with temperature (negatively at $-0.57,-0.65$ ), which is only obvious, and temperature is well correlated with time (positively; 0.36) (exhibiting the time trend), the correlation of PS and NS with time is close to nil $(0.03,0.01)$. The correlation of PS and NS is high (0.76), which seems natural. The observed inconsistency is of a climatic rather than a numeric nature, since the time-temperature correlation, while strongly significant, is far from being close to 1 . An additional check was performed on the situation. The correlation of NS with de-trended temperature was calculated. The increase of the correlation coefficient (from 0.653 to 0.704 ) is small, however it explains a $16 \%$ increase in the variability. This means that the removal of the time trend from the temperature record makes the snow precipitation even better correlated (negatively) with temperature. It indicates (is the result of) the lack of any trend in precipitation. (Calculation of de-trended temperature: $\mathrm{T}_{\mathrm{det}}=\mathrm{T}-0.0196^{*} \mathrm{Time}+39.31$, where Time $=1863,1864, \ldots$ 2008, and the numerical parameters are from the regression, Table 3). Figure 4 shows the variation of the number of days with snowfall with temperature, which was plotted to a reversed scale to bring the two plots together in that graph.

For the purpose of precipitation change forecasting it is very important of learn about relationships between the ratio of the snowfall to total winter precipitation (PS/PT) and air temperature (Przybylak 2002). Figure 5 shows long-term changes of this ratio. During three winter seasons, i.e. 1885/86, 1928/29 and 1939/40, the PS/PT ratio reached its highest levels at more than $80 \%$. During seven other winter seasons, i.e. 1865/66, 1900/01, 1915/16, 1924/ 25, 1950/51, 1993/94 and 2007/08 it was at its lowest at less than 10\%. During the second half of the 20th c., the PS/PT ratio is observed to drop markedly, but looking at the entire 1863-2008 series this trend to the decrease is insignificant ( $p$-value 0.13, Table 3).

The ratio of snowfall to total winter precipitation (PS/PT) is the quantity exhibiting the best correlation with temperature $(r=-0.73)$. To explore the correlation in the course of the

Table 5 The Mann-Kendall test of trend. The standardized normal variable $\mathrm{z}$ is given (values below -2 or above 2 are significant at $\alpha=0.05$ )

\begin{tabular}{lllllllll}
\hline NM & T & PM & NT & PT & NL & PS & NS & PL \\
\hline 6 & 4.7 & 4.1 & 3.5 & 2.7 & 1.4 & 0.5 & 0.1 & -0.1 \\
\hline
\end{tabular}




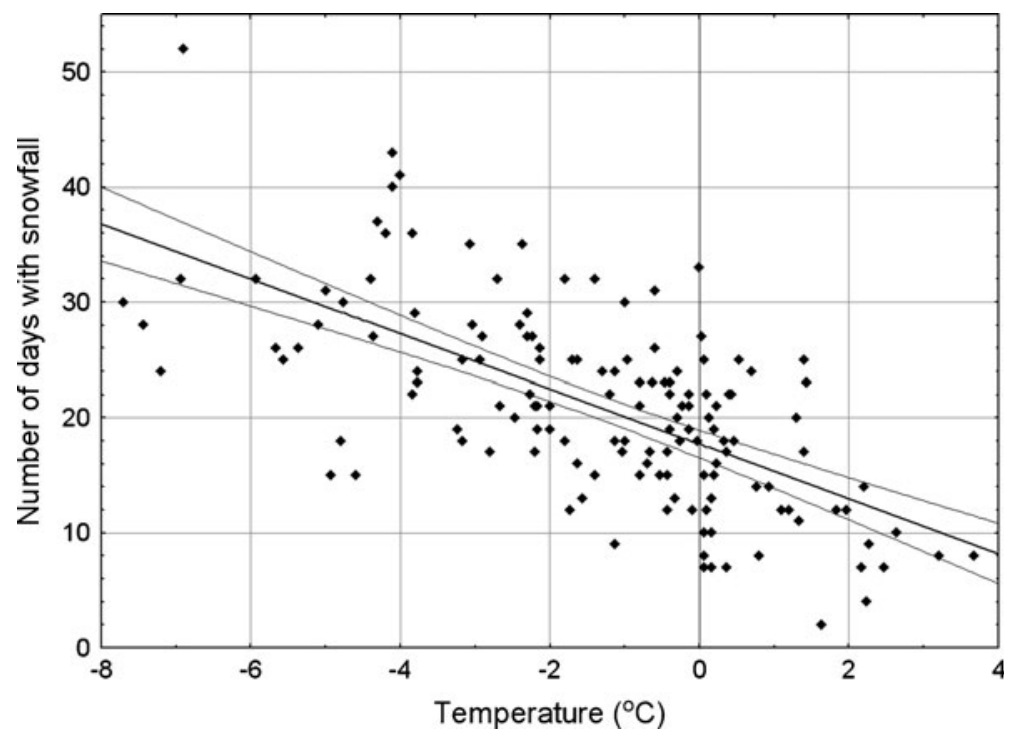

Fig. 3 Dependence of number of days with snowfall on mean air temperature in winter with the $95 \%$ confidence band for the regression line added

time span considered, 30-year moving correlations were calculated (Fig. 6). The plot shows that the highest correlation (in the absolute sense) exceeds the value of -0.8 , while the lowest individual (nor smoothed) value is -0.6 , which is still well beyond the significance limit of -0.36 (two-sided test, $\alpha=0.05$ ). General features of the plot seem to be statistically significant, especially the deepest dependence on the temperature around 1930, as well as around 1970.

In order to capture the relationship between multiple variables, PCA was carried out on wintertime precipitation as a whole (Fig. 7) and on each individual month (Fig. 8). Time and air temperature were added to the chart as the additional variables as they displayed some degree of correlation. It is quite obvious that the variability explained by the first two components is the greater as the number of variables considered decreases. As far as winter precipitation is concerned (8 variables plus two

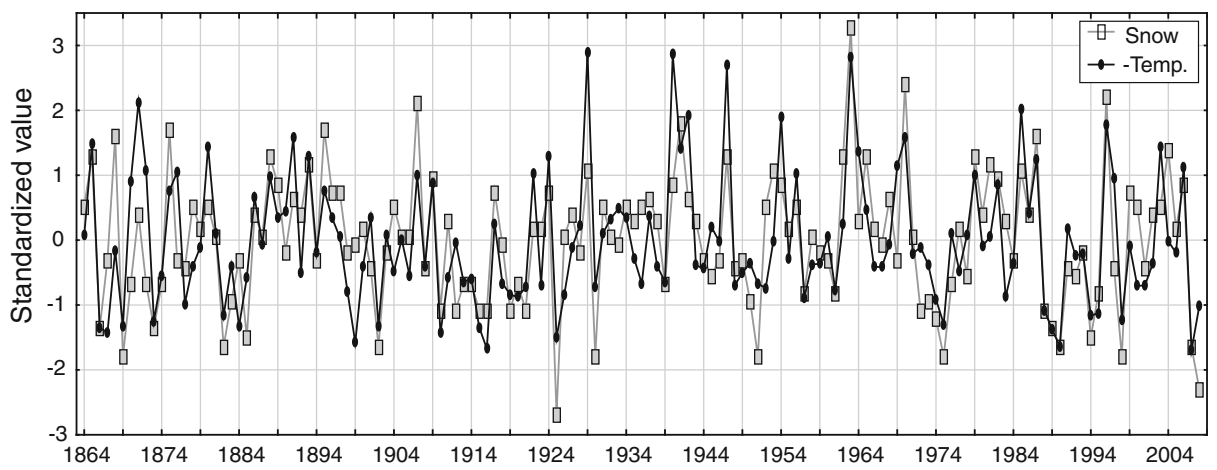

Fig. 4 Standardized values of the reversed de-trended temperature $\left(-\mathrm{T}_{\mathrm{det}}\right)$ and the number of days with snowfall (NS). The last was transformed before standardization by the proper BoxCox transform in order to remove the natural skewness (the number of days is a nonnegative quantity) 


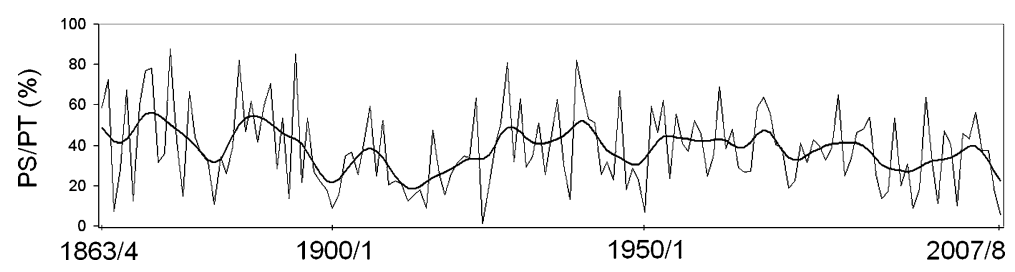

Fig. 5 Variation of PS/PT ratio; smooth curves are obtained by Gaussian filtering

additional ones), the first principal components comprise $38 \%$ and $35 \%$ of total variability, respectively. It is interesting that both values are similar, while the third PC has only 14\%. This means that the first PC (see Fig. 7), which can be identified with time (year), is only slightly more important than the other variability expressed by the second PC. As is clear from the plot, the vertical axis (PC2) is defined by the Snow-Liquid opposition. In addition temperature (an additional variable, which does not define the axis) is roughly parallel to the vertical axis in the direction defined by the liquid precipitation, which is natural. The first factor (horizontal axis) is defined by the variables correlated with time, which is in agreement with the position of the additional variable Time.

If more variables are taken into account (namely 21 monthly characteristics) the percentage of the variability contained in the first two principal components cannot be too high. In any case the general features visible in Fig. 7 are repeated in Fig. 8 with insignificant rotation. Virtually all variables connected with snow (S) are in opposition to temperature, however, the February characteristics are less dependent on temperature, becoming closer to the direction of time. The best correlates of time are, consequently, the characteristics of mixed precipitation.

\subsection{Precipitation and NAO}

Many studies have demonstrated that the influence of the North Atlantic Oscillation, which is an index representing the inflow of air masses from the west (for the positive phase), on precipitation in Central Europe was at its strongest in winter (e.g. Niedźwiedź et al. 2009).

The NAO has a significant impact on both the number of days and the totals of both rainfall and snowfall in the whole winter season (Fig. 9), as well as in particular winter months (Table 6). The extreme positive, as well as negative correlations found in Table 6 are illustrated on Fig. 10a,b. As NAO increases, reflecting an increased western influx (positive phase), so do NL and PL, while NS and PS diminish. The effect has

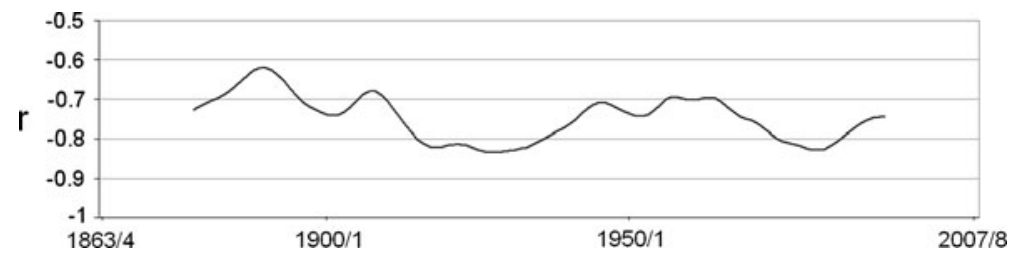

Fig. 6 Moving (30 year window) correlation coefficient between PS/PT ratio and winter temperature; (curve smoothed by Gaussian filtering) 


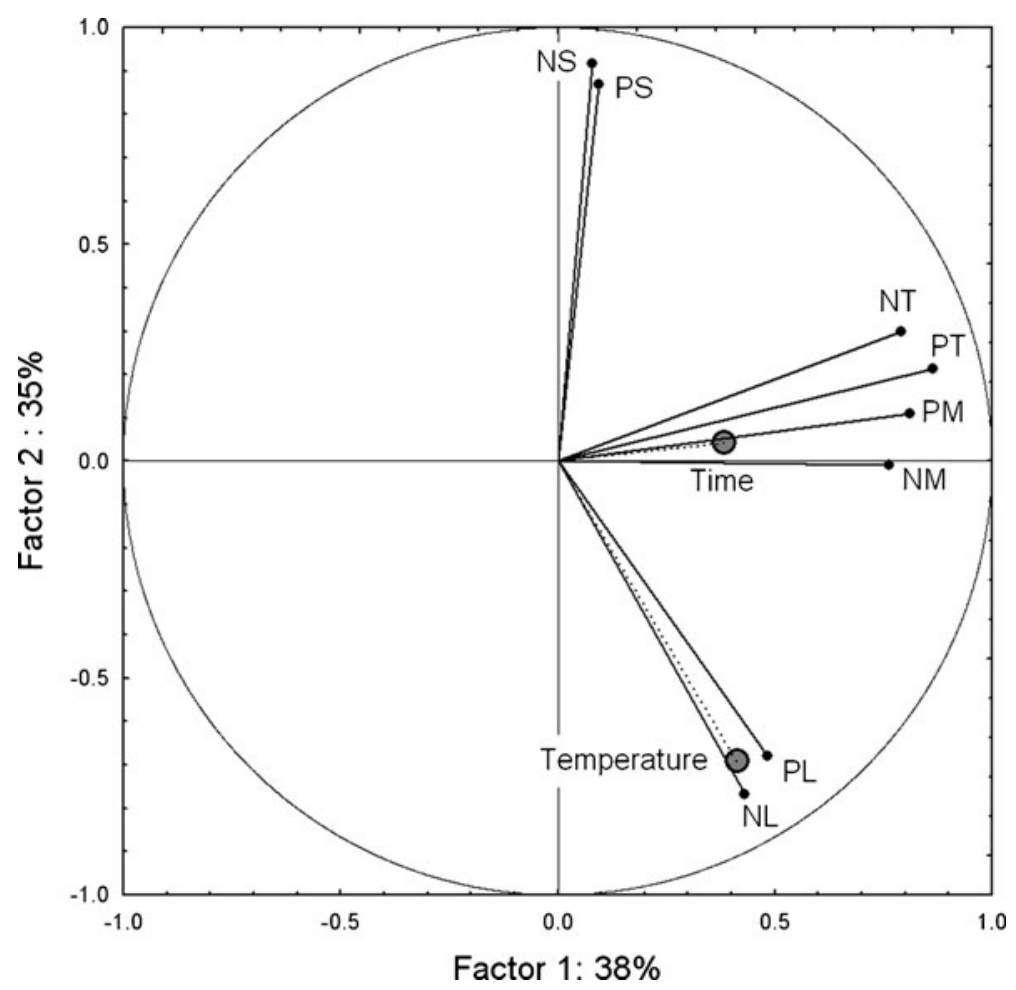

Fig. 7 Principal Components Analysis was performed for 8 variables in winter: averages of precipitation (P), and numbers of days $(\mathrm{N})$ with the given form of precipitation (T-total, $\mathrm{L}-$ liquid, $\mathrm{M}-$ mixed, $\mathrm{S}-$ snow). Winter temperature and simple time (year) are plotted as additional variables

to do with the incoming warmer air masses from over the Atlantic Ocean which causing a rise in temperature. There is no correlation between NAO and either of the mixed precipitation parameters, except the number of days in February (NMF). A detailed analysis is necessary to explain this effect and it will require details of regional-scale circulation, as well as air temperature data. In general, the North Atlantic Oscillation accounted for $27 \%$ of the variance in snowfall totals in winter, which are connected mainly with a negative phase of NAO. The influence of large scale circulation (NAO) on winter precipitation is greater than a potential local urban heat island effect, which is at its highest during anticyclonic situations when precipitation is rather rare.

The dependence of NS on time, temperature and the NAO is well illustrated by the result of the multiple regression, where NS variability is explained by three independent variables in as much as $50 \%$ (corrected $\mathrm{R}^{2}=0.501$, in the case of $\mathrm{PS}$ the $\mathrm{R}^{2}=0.39$ ). The regression formula is:

$$
\mathrm{NS}=(0.045 \pm 0.013)^{*} \text { Time }-(2.4 \pm 0.4)^{*} \text { Temperature }-(1.1 \pm 0.5)^{*} \mathrm{NAO}-(70 \pm 27)
$$

The influence of the independent variables is illustrated by the relative error of the respective regression coefficient; however the simplest method here is to observe the 


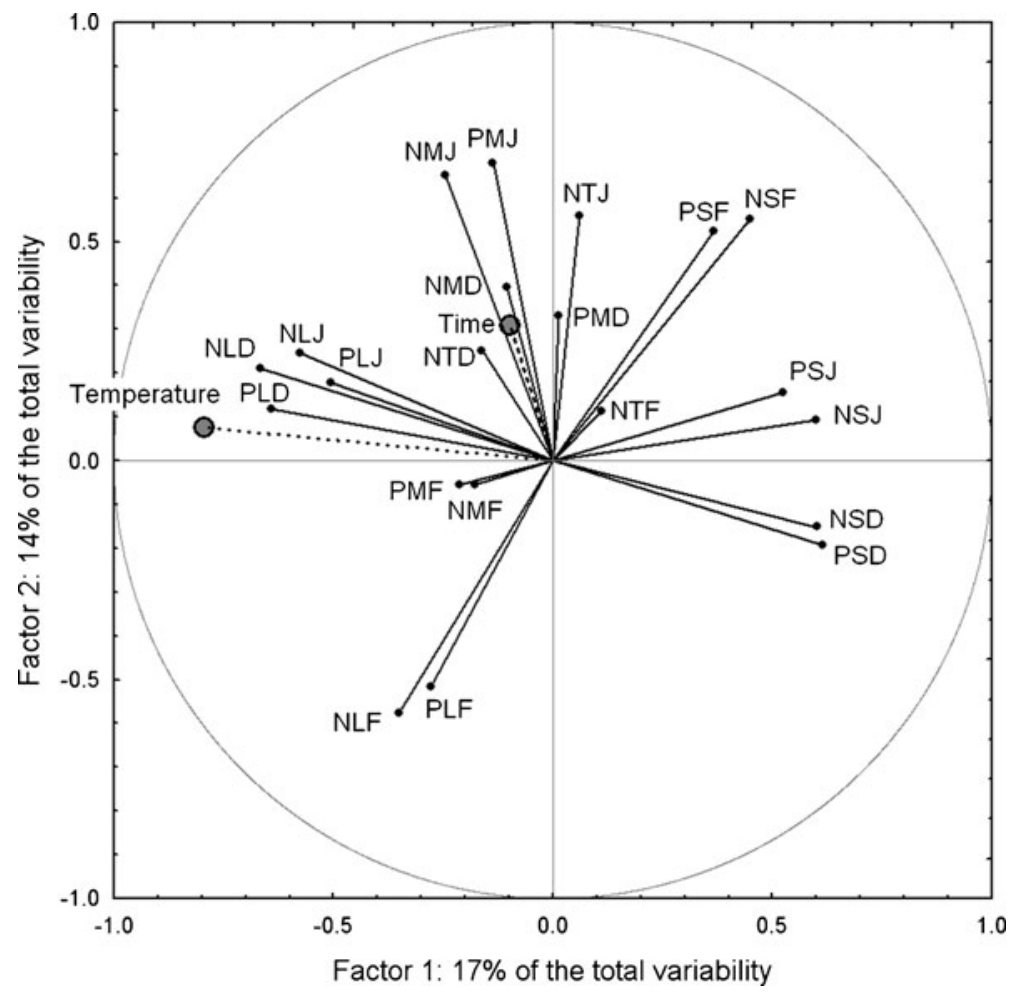

Fig. 8 Principal Components Analysis was performed for 21 variables: monthly averages of precipitation, and monthly numbers of days with the given form of precipitation. The data are treated separately for December, January, and February. Winter temperature and simple time (year) are plotted as additional variables

Student's $t$ values. The highest $t$, indicating the highest influence, is obtained for temperature $(t=8.5)$, next is time $(t=3.4)$, and NAO $(t=2.1)$. The timing of the influence is significant in this multiple regression since it is to be removed from the most important

Fig. 9 Correlation of winter precipitation characteristics with the NAO index. The limits of the statistical significance (at $\alpha=0.05$ ) are plotted

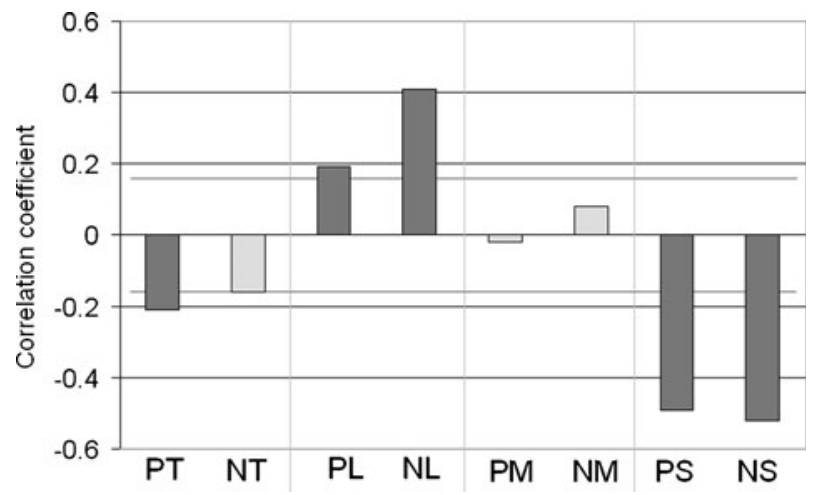


Table 6 Correlation of precipitation and NAO. Values with significant correlations are printed in bold type

\begin{tabular}{lrrr}
\hline Precipitation characteristics & January & February & December \\
\hline PL & $\mathbf{0 . 3 9}$ & $\mathbf{0 . 2 3}$ & $\mathbf{0 . 2 3}$ \\
PM & -0.01 & 0.16 & 0.05 \\
PS & $-\mathbf{0 . 4 5}$ & $-\mathbf{0 . 4 5}$ & $\mathbf{0 . 3 2}$ \\
NL & $\mathbf{0 . 5 2}$ & $\mathbf{0 . 4 5}$ & $\mathbf{0 . 3 0}$ \\
NM & 0.16 & $\mathbf{0 . 2 7}$ & 0.07 \\
NS & $-\mathbf{0 . 5 0}$ & $-\mathbf{0 . 4 5}$ & $-\mathbf{0 . 3 7}$ \\
NT & -0.05 & 0.00 & 0.03 \\
\hline
\end{tabular}

variable, i.e. temperature. The NAO, steering temperature, is the least important as an independent factor.

\section{Conclusions}

The paper used the secular precipitation record of Kraków to illustrate long-term variability of snowfall, rainfall and mixed precipitation in relation to air temperature and North Atlantic Oscillation during the winter season. The results suggest that change can be identified in the overall total and frequency of winter precipitation and in mixed precipitation (positive trend). This means that wintertime precipitation trends are linked to changes in air temperature, which displays the strongest increase during this season.

Rainfall and snowfall are also strongly dependent on temperature, but no significant long-term trend is found. Indeed, these forms of precipitation display a strong variability in time, as a consequence of equally as high variability of circulation conditions in the temperate zone that is dominated, particularly in winter, by cyclonic activity. What this means is that only a very large change in the amount of precipitation has a potential of statistical significance. Another reason for the inconsistencies in the direction of trends of precipitation and temperature may be the location of the station in the centre of a large city. The significant temperature trend may also be a result of a growing urban effect, which has no impact on synoptic situations that bring precipitation. The climate warming effect, however, has contributed to a marked decrease of the PS/PT ratio (snow to total precipitation in winter) in the second half of the 20th c.

The study demonstrates that air temperature has an impact on the frequency and amount of winter precipitation, but this impact is complex and depends also on other factors, including circulation, which is responsible for the water vapour content in the air.

The study showed that:

- Much of the variability in the number of days with snowfall (42\%) is accountable on the basis of air temperature.

- Snowfall and rainfall are strongly, albeit differently, correlated with atmospheric circulation. The higher the NAO value the higher the frequency and amount of rainfall, but the lower the frequency and amount of snowfall. This NAO effect is at its strongest in January when it explains $27 \%$ of the number of days with rainfall and $25 \%$ of snowfall.

- Should the growing trend in air temperature continue it should be expected that snowfall will start decreasing in southern Poland and so will the amount of water from 
a

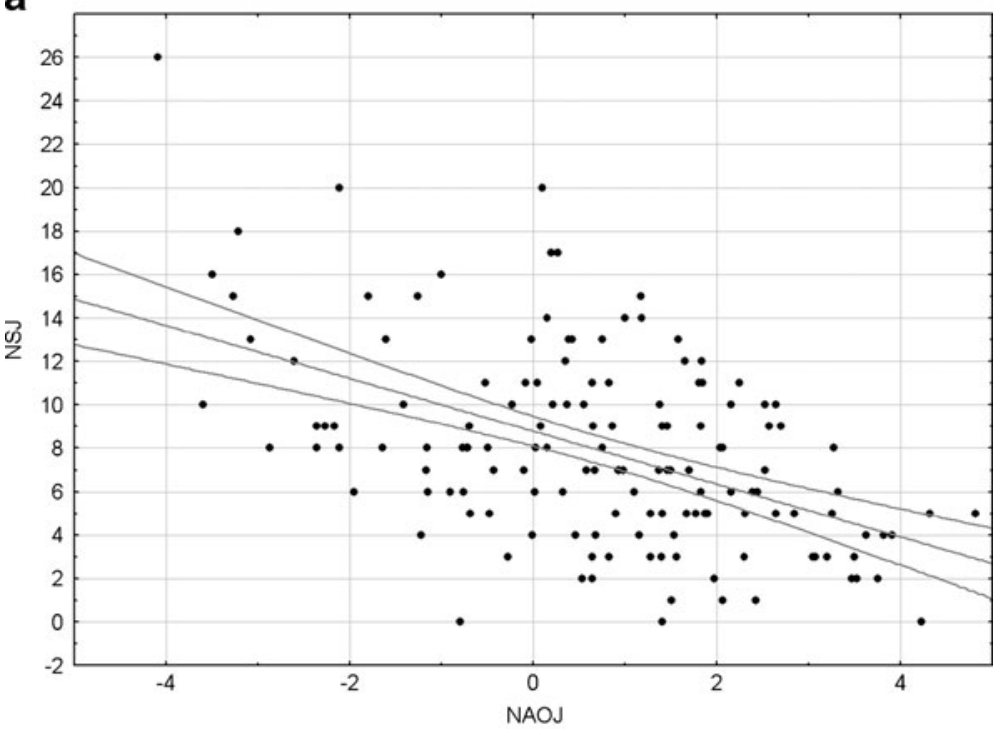

b

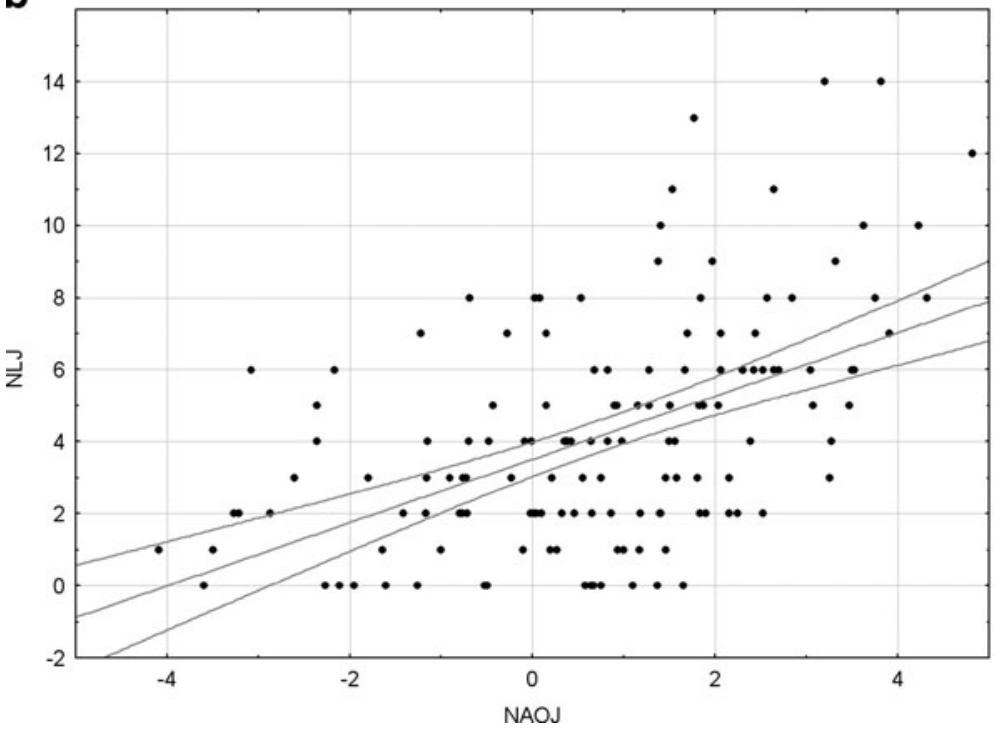

Fig. 10 Scatter plots illustrating the dependence of the number of days with snowfall (NS) and liquid precipitation (NL) in January on the NAO index. The linear regression line is plotted as well as it's confidence bound (95\%)

that snowfall. To reduce the expected number of days with snowfall to nil, however, air temperature would have to increase up to $7.5^{\circ} \mathrm{C}$.

Acknowledgements We thank Mr. Paweł Pilch and Dr. Martin Cahn for reviewing the English. This work was partially supported by the Polish Ministry of Science and Higher Education under Grant No. N N306 119936. 
Open Access This article is distributed under the terms of the Creative Commons Attribution Noncommercial License which permits any noncommercial use, distribution, and reproduction in any medium, provided the original author(s) and source are credited.

\section{References}

Davis RE, Lowit MB, Knappenberger PC, Legates DR (1999) A climatology of snowfall-temperature relationships in Canada. J Geophys Res 104:11985-11994

Goyon I, Elisseeff A (2003) An introduction to variable and feature selection. J Mach Learn Res 3:11571182

Hantel M, Ehrendorfer M, Haslinger A (2000) Climate sensitivity of snow cover duration in Austria. Int J Climatol 20:615-640

Huntington TG, Hodgkins GA, Keim BK, Dudley RW (2004) Changes in the proportion of precipitation occurring as snow in New England (1949-2000). J Climate 17:2626-2636

Hurrell JW (1995) Decadal trends in the North Atlantic Oscillation and relationships to regional temperature and precipitation. Science 269:676-679

IPCC (2007) Climate Change, The Physical Science Basis. Contribution of Working Group I to the Fourth Assessment Report of the Intergovernmental Panel on Climate Change. In: Solomon S, Qin D, Manning M, Chen Z, Marquis M, Averyt KB, Tignor M, Miller HL (eds). Cambridge University Press, Cambridge, United Kingdom and New York, NY, USA, 2007

Jaagus J (1997) The impact of climate change on the snow cover pattern in Estonia. Clim Change $36: 65-77$

Jones PD, Jonsson T, Wheeler D (1997) Extension to the North Atlantic Oscillation using early instrumental pressure observations from Gibraltar and South-West Iceland. Int J Climatol 17:1433-1450

Karl TR, Groisman PY, Knight RW, Heim RR (1993) Recent variations of snow cover and snowfall in North America and their relation to precipitation and temperature variations. J Climate 6:1327-1344

Ke CQ, Yu T, Yu K, Tang GD, King L (2009) Snowfall trends and variability in Qinghai, China. Theor Appl Climatol 98:251-258

Kossowska-Cezak U (2009) Warunki termiczne i opadowe w świetle serii obserwacyjnej z Okęcia (19472008). Zeszyty Naukowe Szkoły Wyższej Przymierza Rodzin w Warszawie, seria GeograficznoTurystyczna 2:25-32

Kożuchowski K (ed) (2004) Skala, uwarunkowania i perspektywy współczesnych zmian klimatycznych w Polsce. Zakład Dynamiki Środowiska i Bioklimatologii UŁ, Łódź

Kożuchowski K, Żmudzka E (2003) 100-year series of areally averaged temperatures and precipitation totals in Poland. Acta Univ Wratislaviensis 2542:116-122

Laternser M, Schneebeli M (2003) Long-term snow climate trends of the Swiss Alps (1931-99). Int J Climatol 23:733-750

Namias J (1985) Some empirical evidence for the influence of snow cover on temperature and precipitation. Mon Weather Rev 113:1542-1553

Niedźwiedź T, Twardosz R, Walanus A (2009) Long-term variability of precipitation series in east central Europe in relation to circulation patterns. Theor Appl Climatol 98:337-350

Przybylak R (2002) Variability of total and solid precipitation in the Canadian Arctic from 1950 to 1995. Int J Climatol 22:395-420

Twardosz R (1997) Pomiary opadów atmosferycznych na stacji meteorologicznej w Krakowie. In: Trepińska J (ed.) Wahania klimatu w Krakowie (1792-1995), Instytut Geografii UJ, 51-58.

Twardosz R (2002-2003) Zmienność opadów śniegu na Pogórzu Wielickim w latach 1971-2000. Folia Geographica, Ser. Geographica Physica 33-34:105-115

Twardosz R (2005) Dobowy przebieg opadów atmosferycznych w ujęciu synoptycznym i probabilistycznym na przykładzie Krakowa (1886-2002). Instytut Geografii i Gospodarki Przestrzennej UJ, p 176.

Twardosz R (2007) Opady atmosferyczne. In: Matuszko D (ed) Klimat Krakowa w XX wieku. Instytut Geografii i Gospodarki Przestrzennej UJ, 127-138

Twardosz R, Cebulska M (2010) Observations and measurements of precipitation in the Polish province of Galicia in the nineteenth century. In: Przybylak R et al (eds) The Polish climate in the European context: an historical overview. Springer Science+Business Media B. V, Berlin, pp $457-471$

Twardosz R, Niedźwiedź T (2001) Influence of synoptic situations on the precipitation in Kraków (Poland). Int J Climatol 21:467-481 
Twardosz R, Niedźwiedź T, Łupikasza E (2010) The influence of atmospheric circulation on the type of precipitation (Kraków, southern Poland). Theor Appl Climatol 104:233-250

Twardosz R, Łupikasza E, Niedźwiedź T (2011) Zmienność i uwarunkowania cyrkulacyjne wystepowania postaci i typów opadów atmosferycznych na przykładzie Krakowa. (Temporal variability in the form and type of precipitation in Kraków in relation to circulation patterns). Wydawnictwo Uniwersytetu Jagiellońskiego, Kraków

von Storch H, Zwiers FW (1999) Statistical analysis in climate research. Cambridge University Press, Cambridge

Ye H (2008) Changes in frequency of precipitation types associated with air temperature over Northern Eurasia during 1936-90. J Clim 21:5807-5819 